\title{
Bush adviser vows to find science its voice
}

Matthew Davis, Washington

Ten months into a presidency that faces a raft of entirely unanticipated challenges at home and abroad, President George W. Bush finally has a science adviser.

John Marburger, the former director of the Brookhaven National Laboratory in New York state was confirmed in the post two weeks ago and has hit the ground running. He's already setting priorities for dealing with the deluge of terror-related research proposals submitted to the White House from various agencies. In addition, he is coordinating technical assessments of methods for improving anthrax detection and mail security, and is imposing a new organizational structure on the White House Office of Science and Technology Policy (OSTP), which he runs.

"Overall, we're getting up to speed after a long hiatus," says Marburger, who has been in Washington working as a consultant to Bush since late September.

But the mild-mannered physicist enters a White House playing-field where the only game in progress is the war on terrorism and it's a contest that is already well under way. Marburger faces a stiff challenge, observers say, in asserting the influence of an office whose ranks have been depleted by neglect.

For example, the influence of a White House science adviser is normally measured by the degree of direct access the adviser has to the president. But on the most pressing scientific issue of the moment - bioterrorism - Marburger's advice will not go directly to Bush, but will instead be channelled through the newly created Office of Homeland Security and its chief, former Pennsylvania governor Tom Ridge.

Furthermore, Marburger is only one of several science advisers Ridge consults. And it has been suggested that Ridge — who will have broad powers in dealing with the antiterror response - may appoint a chief science adviser of his own.

Marburger's influence on budgetary matters could also be limited, at least in the short term, as the 2003 budget proposal is already in its final phases of preparation.

He says he has been heavily involved in budget meetings on research spending, and has talked with the the Office of Management and Budget (OMB) about its plan to apply results-oriented investment criteria to science programmes. He pledges that the administration is "not seeking some crude sort of immediate pay-off" and that the $\mathrm{OMB}$ is "engaged in a serious effort at finding a better way of explaining to Congress and the public why basic, discovery-oriented science" is worth funding.

Marburger is in the midst of reorganizing the OSTP's staff structure. The associate

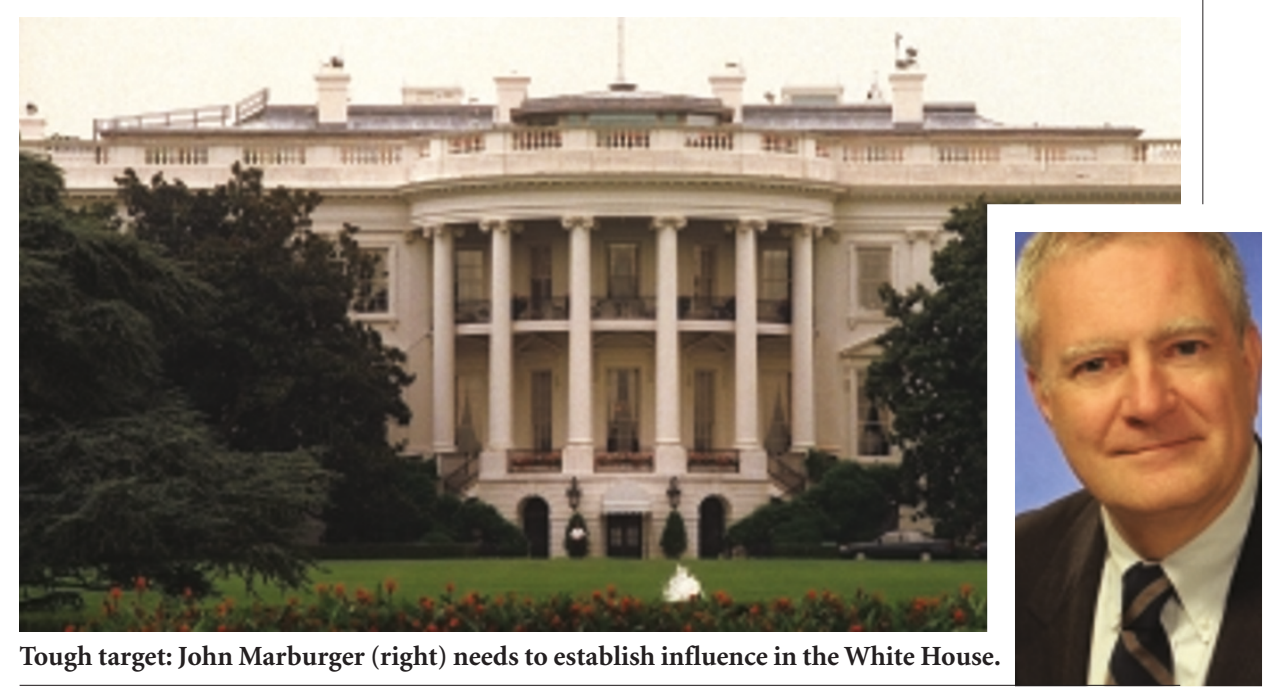

directorships for environment and national security are to go, leaving just two divisions: science and technology.

As for matters that occupied the White

House before 11 September, Marburger says he is looking at climate-change policy but has not spent much time thinking about human embryonic stem-cell research.

\section{Knowledge at stake in Australian poll}

Peter Pockley, Sydney

Australia's opposition Labor Party has sought to make science, technology and education key issues in its campaign for the country's general election on 10 November.

Labor's call for more spending on research and at universities has gained support from unexpected quarters. In Melbourne last month, Australian-born

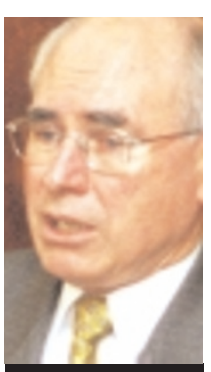

John Howard: "noodle nation". conservative media mogul Rupert Murdoch said: "We need urgent support for our centres of learning. It is no exaggeration to say we are threatened with global irrelevance."

But the warning was rejected by Prime Minister John Howard's governing right-wing Liberal Party, which looked set to lose the

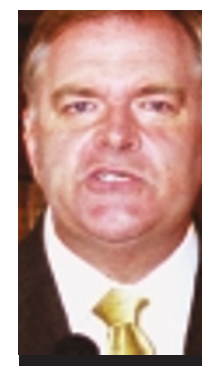
Kim Beazley: tax incentives. Howard is now polling well, after his action to prevent boatloads of asylum-seekers entering Australia and his offer of military help to the United States after the 11 September attacks.

The Labor Party's campaign centres on further funding of research and universities, the first election earlier in the year.

attracted a lot of attention in an Australian election. Under a plan called 'Knowledge Nation' (see Nature 411, 619; 2001), leader Kim Beazley is pledging to double Australia's research spending, as a proportion of the economy, over the next 10 years.

Howard mocks the plan as "noodle nation" and says that his allocation last January of A $\$ 2.9$ billion (US\$1.5 billion) in new research funding over five years, was "the greatest ever single provision for science by any Australian government".

If elected, Labor promises to spend an extra A \$1 billion over five years on engaging more university lecturers. It would increase tax incentives for companies to use research at university and government laboratories, a move that would cost $\mathbf{A} \mathbf{\$ 8 8}$ million per year. The Commonwealth Scientific and Industrial Research Organisation, which has lost 1,000 staff since the Liberal government came to power in 1996, would receive an extra A $\$ 160$ million over five years.

But science leaders doubt that Labor's time these issues have gradual provision of new funds will make its 10-year target attainable. Gavin Brown, chair of the Group of Eight universities (which dominate academic research), estimates that a further A $\$ 13.6$ billion will be needed to match the average research investment of the leading industrial countries by 2005 .

Although Labor has declared its support for the current military action, analysts think that the issue of national security may favour the incumbent government. 